\title{
INTERAKCE KŘESŤANSTVÍ A ZENOVÉ BUDDHISTICKÉ ŠKOLY SANBÓ KJÓDAN
}

M I L O Š HR DÝ

\section{ABSTRACT \\ The Interaction of Christianity and the Sanbo Kyodan}

The Sanbo Kyodan is a contemporary school of Zen that was founded by Yasutani Haku'un Roshi in 1954. Sanbo Kyodan has exerted considerable influence in the development of Zen in the West. Most important for the development of Sanbo Kyodan was Yasutani Roshi's successor, Yamada Koun Roshi. He attracted a number of Western students, many of whom were Christian's priests and nuns.

The paper aims to describe the Christian Zen movement influenced by Sanbo Kyodan. Essential is the work of the most important Yamada Koun's students and verified Zen teachers. Among them were three Roman Catholic priests, Hugo M. Enomiya-Lassalle SJ, Ama Samy SJ and Willigis Jäger OSB, who went on to become leading figures in the Christian Zen movement. The paper attempts to characterize their understanding of the relation between Zen and Christianity including differences among them.

\section{Keywords}

Christianity; Buddhism; Zen; meditation; kensho; Sanbo Kyodan; Haku'un Ryoko Yasutani; Koun Yamada; Hugo Makibi Enomiya-Lassalle; Willigis Jäger; Ama Samy

DOI: $10.14712 / 23363398.2018 .19$

$\mathrm{V}_{\mathrm{e}}$ e 20. století nastala nová intenzivní fáze setkávání křestanství a buddhismu. Buddhističtí učitelé začali cestovat na Západ, aby posluchačům představili učení a praxi buddhismu, a především ve druhé polovině 20 . století se objevili i západní učitelé buddhismu 
všech směrů. Vznikla tak nesmírně pestrá směs více i méně tradičních prrístupů a modifikací. ${ }^{1}$

V této zajímavé interakci západního myšlení s buddhismem² sehrála zcela ojedinělou roli japonská škola Sanbó Kjódan. ${ }^{3}$ Tato v Japonsku početně malá a nepříliš významná skupina nejenže zásadně ovlivnila vnímání a rozvoj zenového buddhismu v USA a v Evropě, ale dala i vzniknout značně unikátní interakci s křestanstvím. Mezi učitele této školy patří nejen významné osobnosti současného buddhismu na Západě, jako např. Robert Baker Aitken ${ }^{4}$ nebo Philip Kapleau ${ }^{5}$, ale i řada křestanů, kteří absolvovali zenový výcvik a získali formální oprávnění vyučovat. ${ }^{6}$ Odtud se odvíjí zajímavá a jistě i diskutabilní interakce křestanství a zenu ${ }^{7}$, která je předmětem tohoto článku.

V první části se budeme věnovat vzniku a učení školy Sanbó Kjódan s důrazem na vztah ke křestanství. Z tohoto pohledu jsou klíčové dvě postavy: Hakuun Rjóko Jasutani, zakladatel Sanbó Kjódan, a druhý opat Kóun Jamada, který sehrál klíčovou roli při interakci s křestanstvím.

Ve druhé části se zaměříme na tři významné křestanské žáky, mezi které patří Hugo Enomiya-Lassalle SJ, Ama Samy SJ a Willigis Jäger OSB.

1 Viz např. Andrew Rawlinson. The Book of Enlightened Masters Western Teachers in Eastern Traditions). 2. vydání. Chicago, LaSalle, IL: Open Court 1998; nebo Harry Oldmeadow. Journeys East. 20th Century Western Encounter with Eastern Religious Tradition. Bloomington, IN: World Wisdom 2004.

2 Přehledný popis historie vnímání buddhismu Západem v Frédéric Lenoir. Setkávání buddhismu se Západem. Praha: Volvox Globator 2002.

3 V práci je používána česká transkripce pojmů z orientálních jazyků dle: Lexikon východni moudrosti. Buddhismus, Hinduismus, Taoismus, Zen. Olomouc: Votobia 1996. V české, anglické a německé literatuře se název Sanbó Kjódan vyskytuje v nejrůznějších variantách (např. Sanbô-Kyôdan, Sanbo Kyodan, Sanbokyodan, Sambokyodan). V současnosti se škola nazývá Sanbó Zen, ale v celém článku je používán původní název Sanbó Kjódan, pod kterým se škola rozšířila mezinárodně.

4 V českém jazyce dostupné Robert Aitken. Vlnazenu. Bašó haikuazen.Praha:Pragma 1995.

5 Autor velmi známé a vlivné knihy Philip Kapleau. The Three Pillars of Zen - Teaching, Practice, and Enlightenment. New York: Anchor Books 2000.

6 Např. Hugo Makibi Enomiya-Lassalle SJ, Willigis Jäger OSB, Ama Samy SJ, Niklaus Brantschen SJ, Johannes Kopp SAC, s. Ludwigis Fabian OSB a s. Elaine MacInnes OLM.

7 Slovo zen je především mahájánová buddhistická škola, která vznikla v 6 . století v Číně ze setkání indického mahájánového buddhismu a čínského taoismu (John C. H. Wu. Zlatý věk zenu. Praha: Pragma 2008, s. 39). Ovšem slovo zen je dnes využíváno $\mathrm{v}$ mnoha dalších významech - především pro meditační praxi této školy, pro zkušenost vycházející z této meditační praxe nebo pro způsob života vyplývající $\mathrm{z}$ dříve uvedeného. Tento významový posun je nejen obrazem posunu ve vnímání zenu, ale často i zdrojem nedorozumění. Na tomto místě se vůbec nezabývám dalšími přenesenými významy slova zen pro minimalistické umění, prostou jednoduchost, kultivovanou spontaneitu, nepřipoutanost atd. 
Všichni byli žáky Kóuna Jamady, byli či jsou vlivnými učiteli zenu, publikovali řadu knih, a co je nejdůležitější, jejich pojetí vztahu zenu a křestanství se liší do té míry, že lze hovořit o třech odlišných typech interakce zenu a křestanství. Důležitou otázkou, která prochází celým článkem, je pojetí kenšó u mistrů školy a vybraných následovníků z křestanského prostředí.

Hlavním zdrojem článku je literatura sepsaná učiteli a křestanskými žáky Sanbó Kjódan, dále oficiální webové stránky Sanbó Kjódan ${ }^{8}$ (včetně částí přístupných pouze pro členy) a stránky křestanských žáků a jejich zenových center. Jako sekundární zdroj slouží knihy a časopisy zabývající se mezináboženským dialogem, ${ }^{9}$ biografie hlavních aktérů a v neposlední řadě literatura na téma křestanské mystiky. ${ }^{10}$

Čtenář může v tomto článku postrádat popis společného základu buddhistického učení, specifik a historického kontextu hlavních směrů, především mahájány a z ní vznikající buddhistické tradice čchan (japonsky zen). Totéž platí o sociálně kulturním kontextu vzniku školy Sanbó Kjódan a jejího šíření do Evropy a USA. V tomto ohledu odkazuji laskavého čtenáře na velice bohatou literaturu. ${ }^{11}$

8 SANBÔ-ZEN oficiální stránka - http://www.sanbo-zen.org/top_e.html.

9 Např. Křestanství a ostatni náboženství. Dokument Mezinárodní teologické komise z roku 1996. Praha: Krystal 1996; Concilium 1988. Christian Identity. Special Column 196. Edinburgh: T. and T. Clark; Catherine Cornille. Many Mansions? Multiple Religious Belonging and Christian Identity. Eugene, OR: Wips and Stock 2002; Denisa Červenková. Katolický pohled na náboženskou pluralitu. Univerzita Karlova v Praze: Karolinum 2016; táž. Mnišský mezináboženský dialog. Dingir 2016, č. 2, s. 69-72; Rose Drew. Buddhist and Christian? An Exploration of Dual Belonging. London, New York: Routledge 2011; Pavel Hošek. Na cestě $k$ dialogu. Krestanská víra v pluralitě náboženství. Praha: Návrat domů 2005; William Johnston. Hledáni nové spirituality. Praha: Cesta 1997; týž. Christian Asceticism and Asia. The Way 1994, roč. 34, č. 2, s. 147-158; Hans Küng - Heinz Bechert. Křestanství a buddhismus. Praha: Vyšehrad 1998; Thomas Merton. Mnišská zkušenost a dialog mezi Východem a Západem. Salve 1992, roč. 2, č. 3, s. 17-20; Dale S. Wright. Satori and the Moral Dimension of Enlightenment. Journal of Buddhist Ethics 2006, roč 13.

10 Např. Stefano de Fiores - Tullo Goffi. Slovnik spirituality. Kostelní Vydří: Karmelitánské nakladatelství 1999; Reginald M. Dacík. Prameny duchovního života. Přehled theologie asketické a mystické. Olomouc: Dominikánská edice Krystal 1947; Louis Komjathy (ed.). Contemplative Literature. A Comparative Sourcebook on Meditation and Contemplative Prayer. State University of New York 2015; Josef Sudbrack. Mysti-

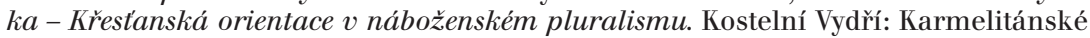
nakladatelství 1995; Evelyn Underhill. Podstata mystiky a jiné eseje. Praha: Dybbuk 2008. Gerald G. May. Will and Spirit. A Contemplative Psychology. New York: Harper Collins Publishers 1982.

11 Např. Heinrich Dumoulin. Zen Buddhism: A History - Volume 2, Japan. Bloomington, IN: World Wisdom 2005; Paul Williams - Anthony Tribe. Buddhistické myšlení. Úplné uvedeni do indické tradice. Praha: ExOriente 2011; Jan Honzík (ed.). Jednota 


\section{Sanbó Kjódan}

\subsection{Zakladatel: Hakuun Rjóko Jasutani}

Sanbó Kjódan byla založena Hakuunem Rjóko Jasutanim (18851973) v roce 1954. Přestože základní charakter převzala škola z linie Sótó ${ }^{12}$, integruje i způsob zenového výcviku linie Rinzai ${ }^{13}$, především studium kóanu.

Róši ${ }^{14}$ Jasutani se stal buddhistickým mnichem v 5 letech a ve 13 letech buddhistickým knězem v linii Sótó. Kolem jeho čtyřicátého roku u něho vyvrcholila osobní krize. I když aktivně přednášel, pocitoval rostoucí nespokojenost: „Byl jsem naprosto slepý člen a má mysl ještě nebyla v klidu.“" ${ }^{\text {K15 }}$ dyž již nemohl dále pokračovat $\mathrm{v}$ tom, co považoval za prázdné přednášení, potkal učitele Daiun Sógaku Haradu, pod jehož přísným vedením strávil 20 let a ke kterému cítil až do smrti

$v$ rozmanitosti - Buddhismus $v$ České republice. Praha: DharmaGaia 2010; Robert C. Lester. Buddhismus. Cesta k osvícení. Praha: Prostor 1997; John C. H. Wu. Zlatý vék zenu. Praha: Pragma 2008; Vladimír Miltner. Vznik a vývoj buddhismu. Praha: Vyšehrad 2012; D. T. Suzuki. An Introduction to Zen Buddhism. London: The Random House Group, reprint 1991; týž. Zen Buddhism. Selected Writings of D. T. Suzuki. New York: Three Leaves Press 2006; týž. Essays in Zen Buddhism. London: Souvenir Press, reprint 2010; Harry Oldmeadow. Journeys East. 20th Century Western Encounter with Eastern Religious Tradition. Bloomington, In: World Wisdom 2004; Andrew Rawlinson. The Book of Enlightened Masters (Western Teachers in Eastern Traditions). Chicago, LaSalle, IL: Open Court, 2. vydání 1998; Robert Sharf. Whose Zen? Zen Nationalism Revisited. In: James W. Heisig - John Maraldo (eds). Rude Awakenings: Zen, the Kyoto School, and the Question of Nationalism. Honolulu: University of Hawai 'i Press 1995, s. 40-51; týž. Sanbōkyōdan: Zen and the Way of the New Religions. Japanese Journal of Religious Studies 1995, roč. 22, č. 3-4, s. 417-458; Brian Daizen Victoria. Zen at War. 2. vydání. USA, MD: Rowman \& Littlefield Publishers 2006; Horace Neill McFarland. The Rush Hour of the Gods: A Study of the New Religious Movements in Japan. New York: Harper \& Row 1970.

12 Sótó - vedle školy Rinzai nejvýznamnější škola zenu. Z Číny byla tato škola přenesena do Japonska mistrem Dógenem Zendžim v 1. polovině 13. století. Hlavní důraz je kladen na intenzivní meditaci vsedè. Srov. Lexikon východni moudrosti. Olomouc: Votobia 1996, s. 404-405.

13 Rinzai - jedna z nejvýznamnějších škol zenu (čchanu) v Japonsku a Číně. Zdůrazňovány jsou kóany jako zvláštní rychlá cesta k osvícení (kenšó, satori). Kóan je krátký příběh nebo úkol, který obsahuje paradox a je logickým a pojmovým chápáním neřešitelný. K jeho řešení je třeba jiné roviny chápání. Srov. Lexikon východni moudrosti, s. 367.

14 Róši - „starý mistr“, označení pro zenového mistra. Srov. Lexikon východní moudros$t i$, s. 369.

15 Koun Yamada. The Stature of Yasutani Hakuun Rōshi. The Eastern Buddhist 1974, roč. 7, č. 2, s. 109. 
obrovskou vděčnost. První seššin ${ }^{16}$ s Haradou absolvoval ve 41 letech a již za dva roky mu jeho učitel potvrdil, že dosáhl kenšó ${ }^{17}$.

Od mládí pro něho byly důležité dvě otázky: Proč ztratilo kenšó svou důležitost, když z dostupných záznamů, které studoval, je zřejmé, že všichni následovníci Buddhy bez jediné výjimky měli tuto zkušenost, a proč současní buddhističtí učitelé neukazují cestu ke kenšó a nevedou k němu své žáky? Druhá otázka se týkala toho, co je po smrti. Tehdejší učitelé školy Sótó mu nebyli schopni dát uspokojující odpověd." ${ }^{18}$

Jasutani se stal silným kritikem mnichů linie Sótó, kterým vytýkal především jejich upoutanost k ceremoniálům a zanedbávání pravé podstaty buddhismu, tj. realizaci pravého já (kenšó). Jasutani byl přesvědčen, že učení buddhismu zdegenerovalo, a byl znám velmi ostrými odsudky na adresu profesorů a lektorů buddhistických univerzit: „Jsou neodpustitelný gang d'áblů, velcí zloději nebe a země, a měli by být nazýváni havětí v těle lva. Neuvědomují si, že jsou bídní lidé, špinící Tři poklady, a že musí po smrti padnout do pekla““19

V lednu 1954 zakládá Sanbó Kjódan bez formálních vazeb na školu Sótó s cílem obnovit pravé učení zenu a nabídnout ho opravdovým hledačům „Cesty“, a to i laikům. „Sanbó“ znamená „tři poklady“ a označuje tři základní prvky buddhismu: Buddhu, dharmu a sanghu. „Kjódan“ pak znamená „náboženskou organizaci“. Název měl vyjadřovat Jasutaniho úmysl a cíl vytvořit náboženské společenství, které bude zcela oddáno zachování a předávání pravé buddhistické cesty. ${ }^{20}$

Jasutani se upnul na propagaci nezastupitelného místa kenšó v zenu. Jeho život byl plný konfliktů. Jeho kritika především školy Sótó, ale i směru Rinzai byla často sžíravá a jeho postoje proti tomu, co považoval za zlo, byly absolutní. Jeho slova o nutnosti „zničit ty zlé

16 Seššin - dny mlčení a intenzivního denního mnohahodinového cvičení zazenu (meditace vsedě), přerušovaného pouze spánkem v noci a krátkými přestávkami po jídle; součástí jsou recitace, práce (jen krátce), přednášky a rozhovory s mistrem. Srov. Lexikon východni moudrosti, s. 392-393.

17 Kenšó (vhled do vlastní podstaty) - zenový výraz pro zážitek probuzení (osvícení) má obvykle stejný význam jako satori (od satoru, tj. poznávat), ale někdy se výraz kenšó používá pro počáteční zkušenost, která na rozdíl od satori potřebuje prohloubení. Pokud nebude řečeno jinak, jsou zde tyto termíny užívány synonymně. Srov. Lexikon východni moudrosti, s. 229.

18 Srov. Koun Yamada. The Stature of Yasutani Hakuun Rōshi, s. 116.

19 Tamtéž, s. 111.

20 Srov. Short History of the Sanbô-Kyôdan - http://www.sanbo-zen.org/histry_e.html (Sanbô-Zen, oficiální webová stránka školy Sanbó Kjódan) [2016-9-18]. 
a ustanovit spravedlivé“ ${ }^{21}$ byla často př́liš vehementní a byl za ně kritizován. Značné odsouzení vyvolaly i Jasutaniho extrémně pravicové a antisemitské názory ${ }^{22}$, které vedly k oficiální omluvě róšiho Kuboty, třetího nástupce ve vedení Sanbó Kjódan. ${ }^{23}$

Navzdory kontroverzím, které vzbuzoval, byl učitelem schopným oslovit řadu žáků a člověkem, jehož zájmem bylo v souladu s tradicí zenu „sebezkoumání, to znamená prozkoumat a uvědomit si své vlastní pravé já (,Self‘)“. ${ }^{24}$ Jasutani měl žáky nejen z Japonska, ale i z Evropy a Spojených států amerických, kde od roku 1962 vedl intenzivní zenové výcviky, a jeho vliv je zde patrný dodnes, především v důrazu na kenšó a na meditační soustředění (seššin). V roce 1970 odešel na odpočinek a vedení předal svému pokračovateli v dharmě róšimu Kóun Jamadovi. ${ }^{25}$

\subsection{Kóun Jamada}

Druhý opat Sanbó Kjódan, Kóun Jamada ${ }^{26}$ (1907-1989), byl ženatý podnikatel se třemi dětmi a nikdy nebyl ordinován na kněze ani nestrávil výrazně dlouhé období v klášteře. Zenu se věnoval od roku 1943 a prostřednictvím róšiho Harady se dostal do kontaktu s Jasutanim, kterého pozval v roce 1953, aby zahájil činnost zenové skupiny „Kamakura Hakuun-kai“ a měsíční seššin. Ve stejném roce ${ }^{27}$ zažil neobvykle hluboké kenšó ${ }^{28}$ a v roce 1967 se stal zenovým mistrem ve škole Sanbó Kjódan. O tři roky později mu Jasutani předal vedení tohoto sdružení.

Stejně jako Jasutani cestoval i Jamada do USA a Německa, kde vedl od roku 1971 pravidelná zenová soustředění, kterých se účastnilo mnoho zahraničních studentů, mezi nimi i katoličtí kněží a řádové sestry. Do roku 1989, kdy Jamada umírá, absolvovaly formální zenový výcvik

21 Koun Yamada. The Stature of Yasutani Hakuun Rōshi, s. 120.

${ }^{22}$ Brian Daizen Victoria. Zen at War. Maryland: Rowman \& Littlefield Publishers, 2. vydání 2006, s. 137.

23 Omluva byla uveřejněna v oficiálním periodiku Kyosho č. 281 v roce 2000 (http:// www.thezensite.com/ZenEssays/CriticalZen/Apology.html [2016-10-05]).

24 Masao Abe. Transformation in Buddhism in Comparison with platonic and Christian Notions. Concilium 1988, Special Column 196, Christian Identity. Edinburgh: T. and T. Clark, s. 53.

25 Srov. Short History of the Sanbô-Kyôdan - http://www.sanbo-zen.org/histry_e.html (Sanbô-Zen, oficiální webová stránka školy Sanbó Kjódan) [2016-9-18].

26 Srov. tamtéž.

27 Někdy je uváděno, že kenšó dosáhl až v roce 1954. Např. Taizan Maezumi in: Koun Yamada. The Gateless Gate. The Classic Book of Zen Koans, s. 297.

28 Jeho záznam byl publikován v: Philip Kapleau. The Three Pillars of Zen-Teaching, Practice, and Enlightenment, s. 228-232. 
pod jeho vedením více než dvě desítky nejaponských žáků a více než tucet svých křestanských žáků formálně pověřil učením zenu. ${ }^{29}$

Interakci s křestanstvím přikládal Jamada velký význam a věřil, že „zen se jednou stane důležitým proudem v katolické církvi““. ${ }^{30}$ Ve své řeči uveřejněné v oficiálním časopise školy Sanbó Kjódan říká: „Jak víme, konečný cíl buddhismu je zachránit všechny lidi: ,vnímajících bytostí je bezpočet, slibuji všechny zachránit'. To je v současném buddhismu nemožné. Bez spolupráce s katolíky, bez spojení našich sil, nebudeme schopni to udělat." ${ }^{\text {(51 }}$ A dále pak pokračuje: „Když křestané, zvláště katolíci, se naučí brát svět jako jedno, nebude už více západní duch; a samozřejmě nebude už východní duch. Bude jeden univerzální duch. Cítím, že abychom zachránili lidský druh - přinesli pravé štěstí všem lidem -, katolicismus a zen musí spojit ruce.632

Křestanští žáci z Evropy a USA, z nichž mnozí byli řádoví mniši a mnišky, tvořili důležitou část zenové komunity kolem róšiho Jamady. Ten je jako křestany ochotně přijímal. Někteří z nich měli za sebou léta řádové formace, ${ }^{33}$ která obsahovala tradiční prvky křestanské duchovní cesty (teologickou četbu, studium Písma, praxi v rozjímavé modlitbě, pěstování ctností atd.). Domnívám se, že ve spojení s velkou motivací postoupit na své duchovní cestě lze předpokládat, že byli výjimečně disponováni na postupný přechod od modlitby rozjímavé ke kontemplativní. Otevřenost róšiho Jamady, možnost cvičení zazenu podle propracované metody a vedení osvíceného učitele tak mohly vést k rychlému zvnitřnění modlitby, k utišení distrakcí a k duchovnímu vhledu. Jak bude ukázáno, pozitivní vliv zenové meditace na duchovní rozvoj potvrzují všichni bez ohledu na rozdílnosti v jejich názorech na vztah zenu a křestanství. ${ }^{4}$

Jamadovo učení a vedení žáků bylo v souladu s učením zakladatele Sanbó Kjódan zaměřeno především na dosažení kenšó. Ruben Habito ${ }^{35}$

29 Srov. Ruben L. F. Habito. In Memoriam: Yamada Koun Roshi. Christian Studies 1990, roč. 10, s. 232-233.

30 Robert Sharf. Sanbōkyōdan: Zen and the Way of the New Religions. Japanese Journal of Religious Studies 1995, roč. 22, č. 3-4: Special Edition: The New Age in Japan, s. 423.

31 Koun Yamada. Christian Practitioners of Zen. Kyosho 2012, č. 356, s. 33.

32 Tamtéž, s. 35.

33 Srov. Řehole svatého Benedikta. Praha: Čeští benediktini 1993; Konstituce Tovaryšstva Ježišova. Česká provincie Tovaryšstva Ježíšova 1999.

34 Zcela jiná situace pak nastává, když tito žáci už jako učitelé uváděli své žáky do zenové meditace bez přípravy, kterou sami absolvovali.

35 Srov. Ruben Habito in: Koun Yamada. The Gateless Gate. The Classic Book of Zen Koans. Boston: Wisdom Publications 2004, s. xii. 
však upozorňuje, že od konce sedmdesátých let až do Jamadovy smrti se akcent jeho učení přesouval od dosažení zkušenosti kenšó k zosobnění a ztělesnění této zkušenosti $\mathrm{v}$ denním životě. Jamada $\mathrm{v}$ daném období prý často upozorňoval, že někteří prožitou zkušenost kenšó idealizují, uctívají a lpějí na ní. Takovou připoutanost považoval za zhoubnější než jiné. Róši Jamada zdůrazňoval, že pravé ovoce zenu se manifestuje, „když lidská bytost je schopna zakusit vyprázdnění vlastního ega a opravdově prožívat svou lidskost s pokorným srdcem, v míru se sebou a universem, se soucitem bez hranic". ${ }^{36}$

Kóun Jamada byl nejen charismatickým učitelem, ale především duchovním otcem rysů školy Sanbó Kjódan, které jsou významné pro pochopení jejího vlivu na západní buddhismus a křestanství. Především jeho zásluhou měla a má Sanbó Kjódan značný vliv na západní vnímání zenu.

\subsection{Tři specifické rysy Sanbó Kjódan}

Domnívám se, že za hlavní rysy a důvody vlivu lze považovat tři faktory. Za prvé, laicizaci, kterou inicioval již zakladatel róši Jasutani, jenž ve své době otevřel možnosti studia zenu laikům do mimořádné míry, ač sám měl tradiční mnišský výcvik. Nutno ovšem dodat, že toto nebylo výlučným rysem Sanbó Kjódan, úsilí o laicizaci lze pozorovat od vlády císaře Meidžiho (1868-1912). ${ }^{37}$

Róši Jamada, který se stal opatem, aniž byl kdy mnichem, pokračoval v laicizaci a často zdůrazňoval nutnost vtělit nejvyšší osvícení do obyčejného denního, tedy laického, života. Dle něho je plně realizovaný zenový člověk ten, kdo odhodil veškeré sebevědomí svého osvícení a žije obyčejný život, ale s jedním podstatným rozdílem: ego již více nevystupuje do popředí, aby kazilo práci. ${ }^{38}$

S tím souvisí i druhý, zcela revoluční rys, a podle některých žákủ ${ }^{39}$ i největší přínos, kterým je prolomení bariéry mezi buddhisty a křestany. Jamada jako první začal přijímat křestany jako křestany, tedy s respektem k jejich náboženství, bez snahy o jejich konverzi k buddhismu. Jasutani, zakladatel Sanbó Kjódan, sice také přijímal křestany za žáky,

\footnotetext{
Tamtéž, s. xii.

37 Srov. Robert Sharf. Sanbōkyōdan: Zen and the Way of the New Religions. Japanese Journal of Religious Studies 1995, roč. 22, č. 3-4: Special Edition: The New Age in Japan, s. 434-436.

38 Srov. Ruben L. F. Habito. In Memoriam: Yamada Koun Roshi. Christian Studies 1990, roč. 10, s. 234 .

39 Srov. tamtéž, s. 235.
} 
ale zastával názor, že křestané nemohou zen řádně praktikovat, a často je kritizoval pro jejich lpění na konceptu Boha, což považoval za překážku osvícení. Naléhal na ně, aby tento koncept odhodili, a tvrdil, že by měli, pokud chtějí praktikovat pravý zen, jít buddhistickou cestou a přijmout pravidla a předpisy buddhismu. ${ }^{40}$ Křestanský zen jako rozporný termín kritizoval i Jasutaniho žák Philip Kapleau s tím, že křestanský teismus je výraznou překážkou osvícení. Kapleau považoval pověřování křestanů učením zenu za bizarní a jejich formální jmenování za hrozbu pro integritu zenu. ${ }^{41}$

Otevření zenu do té míry, že vzniká zenová komunita z oddaných buddhistů i křestanů, je tak zcela novým rysem a zásluhou róšiho Jamady, který začal zdůrazňovat, že zen je cesta čisté zkušenosti. Takový postoj je něčím výjimečným i v rámci zenového buddhismu a je i v současnosti jednou z nejzajímavějších a nejkontroverznějších tezí školy Sanbó Kjódan. Willigis Jäger, benediktinský mnich a jeden z předních žáků Jamady, tak mohl v roce 1987 na Mezinárodní buddhisticko-křestanské konferenci v Berkeley sebevědomě říci: „Mnozí se mohou přít o to, zda křestan může oprávněně dělat zen nebo učit zen. Faktem je, že já tak činím.“42 Tento názor, se kterým Jamada souhlasil, byl přelomový i v rámci Sanbó Kjódan.

Třetím a patrně nejvýznamnějším faktorem je pojetí kenšó a důraz na něj. Kenšó je neopominutelnou součástí zenového buddhismu („Satori je raison d'etre zenu, bez kterého zen není zenem.“43), ale pro Sanbó Kjódan je typický zcela mimořádný důraz na tuto zkušenost.

\subsubsection{Pojetí kenšó}

Jak už bylo zmíněno, otázka, proč kenšó ztratilo důležitost a proč současní buddhističtí učitelé neukazují cestu ke kenšó, byla pro róšiho Jasutaniho jedna z těch nejdůležitějších. A stejně tak pro Jamadu: „Bez probuzení (satori) není zen. Nejsem sám, kdo to tak vnímá. Můj učitel róši Jasutani Hakuun si to také myslel, stejně jako jeho učitel ... róši Harada Daiun. ${ }^{444}$

\footnotetext{
Srov. tamtéž.

41 Srov. Harry Oldmeadow. Journeys East. 20th Century Western Encounter with Eastern Religious Tradition, s. 434.

42 Ruben L. F. Habito. In Memoriam: Yamada Koun Roshi, s. 235.

43 D. T. Suzuki. An Introduction to Zen Buddhism. London: The Random House Group, reprint 1991, s. 95.

44 Koun Yamada. Zen: The Authentic Gate, 2015, s. 12.
} 
Pojetí kenšó je zásadní nejen pro pochopení učení a působení Sanbó Kjódan, ale i pro úvahy o vztahu ke křestanství. Kenšó je per definitionem nepopsatelné a nevyjádřitelné, ${ }^{45}$ nicméně D. T. Suzuki ${ }^{46}$ definuje osm základních znaků osvíceni ${ }^{47} \mathrm{v}$ zenovém buddhismu a na tento popis navazuje James H. Austin ${ }^{48}$ a doplňuje dalších deset charakteristik zkušenosti kenšó. Jimi uváděné znaky shrnuji do čtyř hlavních oblastí: jinakost poznání obsaženého v kenšó, autoafirmativnost, důsledky a fenomenologie zážitku.

Poznání obsažené v kenšó je jiné než běžné poznávání (intuitivnost, ne-racionalita) a nemá nic společného s logikou. Kenšó je intuitivním vhledem na rozdíl od intelektuálního nebo logického porozumění. ${ }^{49}$ Z toho pak vyplývá i nepopsatelnost takové zkušenosti.

Autoafirmativnost je důležitou vlastností kenšó, které je samo sebou pravdivé, akceptující realitu tak, jak ve skutečnosti je (skutečnou skutečnost). Tato zkušenost je svému nositeli tak zřejmá, že nemůže být nikým a ničím účinně zpochybněna. Nutno ovšem upozornit, že tradičně musí být pravost kenšó potvrzena autorizovaným mistrem, což přirozeně vyvolává otázky ohledně výše uvedeného znaku.

Kenšó je jen přechodným zážitkem, ale jeho důsledky jsou nezapomenutelné a trvalé. Tato zkušenost pozitivně mění vidění a chápání světa, sebe samého a vlastní chování. Významné je vnímání jednoty já s veškerým bytím, dokonalost všeho (posvátnost), neosobnost. Důsledkem je ale i neochota intervenovat (vzhledem k dokonalosti všeho a utišení veškerých tužeb já).

Další znaky popisují pomíjivou fenomenologii zážitku. Žáci školy Sanbó Kjódan, kteří dosáhli kenšó, často tuto zkušenost popsali. Jejich

45 Te-šan Süan-tien (jap. Tokusan Senkan), čchanový (zenový) mistr (asi 781-867), po náhlém prohlédnutí spálil své komentáře se slovy: I když jsme mistrně zvládli i ty nejhlubší doktríny, je to přece jen, jako kdyby se jediný vlas položil do širokého prostoru; i kdybychom vyčerpali podstatně vědění světa, je to přece jen, jako když se nechá padnout kapka do velké propasti. Srov. Lexikon východní moudrosti, s. 463-464.

46 Daisetsu Teitaro Suzuki (18. říjen 1870 - 12. červenec 1966) byl japonský filosof a esejista. Jeho texty měly mimořádný vliv na šírení zenu v západním světě, především v USA. Napsal řadu knih, mimo jiné An Introduction to Zen Buddhism z roku 1934 s předmluvou Carla Gustava Junga.

47 Srov. D. T. Suzuki. Zen Buddhism. Selected Writings of D. T. Suzuki. New York: Three Leaves Press 2006, s. 120-127.

48 James H. Austin. Zen and the Brain. Cambridge, MA: The MIT Press 1999, s. 542-544. Austin je klinický neurolog, praktikující zen více než 30 let, a citovaná kniha se stala v roce 1998 vítězem Scientific and Medical Network Book Prize.

49 Srov. D. T. Suzuki. An Introduction to Zen Buddhism, s. 88. 
popisy obsahují znaky jako pocit exaltace, náhlost a krátkodobost, nepř́ítomnost běžného vnímání času, pocit věčnosti a nekonečnosti prostoru, pocit úlevy (fyzické i psychické), zmizení strachu. ${ }^{50}$

Jamadův popis kenšó je $\mathrm{v}$ souladu s výše zmíněným zobecněním hlavních znaků (jinakost poznání, autoafirmativnost, důsledky ve formě změny chápání světa a sebe, fenomenologie). Jedná se o poznání, kdy obsah subjektu i objektu je prázdný a jeden a tato prázdnota-jednota není nic jiného než neustále se měnící jevový svět forem. Aktuální existence je z jedné stránky totálně prázdná a $\mathrm{z}$ druhé stránky je jevovým světem forem, který se neustále, nepřerušeně objevuje (vynořuje) a mizí podle zákona příčiny. ${ }^{51}$

Dle Jamady jenom lidé jsou náboženští, ale ještě dříve jsou lidmi, takže poznání vlastní přirozenosti není náboženství a - protože člověk je stvořen k obrazu Božímu - poznat sám sebe znamená lépe poznat Boha. ${ }^{52}$ Praktikovat zen jako cestu ke kenšó, tj. k sebepoznání, není náboženství. A přestože většinu buddhistických sekt ${ }^{53}$ lze dle něho považovat za náboženství, se zenem je to jinak. ${ }^{54}$ Jamada totiž rozlišuje spiritualitu založenou na víře (ve smyslu věřeného obsahu) a zkušenostní spiritualitu ${ }^{55}$, přičemž za náboženství považuje pouze spiritualitu založenou na víře. Zen je zcela zkušenostní spiritualita, protože odmítá veškeré koncepty jako prostředky poznání pravdy, tj. pravého já. Zen je dle něho výlučně zaměřen na zkušenost sebe-realizace (realizace pravého já), a proto můžeme říci, že zen je jádro buddhismu. Všechny teorie a filosofie různých škol buddhismu jsou jen šaty, kterými přikrášlujeme jádro. Zkušenost pravého já je ale jednoduše fakt, fakt zkušenosti, stejně jako chut́ čaje je fakt. Čaj chutná stejně všem, buddhistovi stejně jako křestanovi. ${ }^{56}$

50 Např. kapitola s názvem Osm současných zkušeností osvícení Japonců a obyvatel Západu in: Philip Kapleau. The Three Pillars of Zen - Teaching, Practice, and Enlightenment, s. 211-299; Satomi Myodo. Journey in Search of the Way. Albany: State University of New York Press 1993.

51 Srov. Koun Yamada. Zen: The Authentic Gate, s. 13.

52 Srov. tamtéž, s. 14. (Jamadovy úvahy a znalosti o křestanství jsou pravděpodobně důsledkem rozhovorů s jeho křestanskými žáky. Domnívám se, že ho ovlivnil především otec Enomiya-Lassalle, kterého si Jamada velmi vážil.)

53

54

55 Srov. Koun Yamada. Zen: The Authentic Gate, s. 15.

„... faith based spirituality as grounded in belief and understanding, whereas experience-based spirituality emphasizes practice, realization, and actualization.“ Tamtéž, s. 11.

56 Srov. tamtéž, s. 13. 
Tento fakt (zkušenost) nás osvobozuje od obav z pozemského utrpení. Nikdo neví, uvádí Jamada, proč má tato zkušenost tak užasnou sílu, ale jednoduše ji prostě má, bez potřeby nějakého konceptu nebo víry. „Může takový fakt být nazván náboženství? Nemyslím. Tento fakt je nazýván ,probuzení, ,realizace (pravého) já‘ nebo ,osvícení a je doprovázen velkým pokojem mysli.“57

Domnívám se, že právě tento koncept zenu jako absolutní zkušenosti za všemi náboženstvími, filosofiemi a myšlenkovými systémy je pro pochopení působení školy Sanbó Kjódan klíčový. Tento ode všech pojmů a konceptů destilovaný zážitek je považován za poslední a pravou zkušenost našeho lidství. A všichni jsme prvotně lidé a až druhotně buddhisté či křestané. Tomuto pojetí nelze upřít přitažlivost a pozitivní potenciál pro mezináboženský dialog a vzájemné porozumění na světové úrovni. Róši Jamada toužil sdílet tuto zkušenost s lidmi v pozici vůdců, politiků, finančníků a manažerů, aby mohli tuto zkušenost realizovat. To by byla dle něho nejrychlejší cesta ke skutečnému světovému míru. ${ }^{58}$

Ohledně kenšó však Jamada zdůrazňuje ještě další velmi zajímavé a často (i západními buddhisty) opomíjené skutečnosti. Především slovo osvícení pokrývá nekonečnou škálu stupňů hloubky a jasnosti této zkušenosti. Každý žák je jiný a vyřešit kóan $M u^{59}$ během týdenního soustředění je osvícení, a osvícení je i dosažení nejhlubších vrstev porozumění po 30 letech praxe. ${ }^{60}$

Připomíná také, že existují tři stupně zenu, zaměřené nejprve na sílu koncentrace, pak na kenšó a posledním stupněm je zosobnění nejvyšší cesty, zdokonalení charakteru. ${ }^{61}$ Mimořádně důležité je, že síla koncentrace nezapříčiní kenšó, a naopak kenšó nezpůsobí silnou koncentraci. ${ }^{62}$ Tedy, přestože je zde souvislost mezi koncentrací a kenšó, není to souvislost jednoduše př́ičinná.

\footnotetext{
Tamtéž, s. 16.

Srov. tamtéž.

59 Kóan zní: Mnich se zeptal Čao-čoua: „Má pes buddhovskou podstatu, anebo nemá?“ Čao-čou řekl: „Mu.“ Mu doslova znamená nic, žádný, ne; ale dle učení mají všechny bytosti bez výjimky buddhovskou podstatu. Srov. Ohrada bez brány. Sbírka klasických činských zenových př́bẻhů sestavená v r. 1229 Mistrem Wu-men Chuej-kchanem (překl. a komentář R. Aitken). Bratislava: CAD Press 2000. Př́ípadně Brána bez dveř́-Wumenguan (překl. Oldřich Král). Praha: Maxima 2007.

60 Srov. Koun Yamada. Zen: The Authentic Gate, s. 99.

61 Srov. tamtéž, s. 39.

62 Srov. tamtéž, s. 41.
} 
Zdá se, že Jamada v posledním období života přestával klást výlučný důraz na kenšó. V předmluvě ke své knize v roce 1979 píše, že zen je v Japonsku na pokraji úplného zániku, a uvádí dva hlavní důvody tohoto stavu. Za prvé, někteří učitelé potvrzují jako kenšó zkušenost, která je evidentně neúplná. A to pak pokračuje dále, takže slepý vede slepého. Druhou příčinou úpadku zenu jsou učitelé, kteří nepochopili, že zenová cesta je nekonečná a že bez ohledu na osobní pokročilost je zde vždy „nekonečné za“ (limitless beyond). ${ }^{63}$

V souvislosti s výše uvedeným se nutně objevuje otázka: Je-li esencí zenu kenšó a zároveň je zde nekonečná škála, které kenšó je to konečné? Dále pak, je-li nejvyšším zenem zdokonalení charakteru, jak s tím souvisí kenšó? Na tyto otázky nedal Jamada jednoznačné odpovědi, a lze se tedy domnívat, že názorová odlišnost jeho křestanských žáků, která bude dále popsána, může mít částečně podklad i v této nejasnosti.

\subsection{Sanbó Kjódan - současnost}

Po třetím opatu, kterým byl Džiun Kubota, stojí od roku 2004 v čele Sanbó Kjódan Rjóun Jamada, syn Kóuna Jamady.

Již za života Jasutaniho se začali někteří jeho žáci osamostatňovat. Kapleau formálně ukončil vztah s Jasutanim v roce 1967. Důvodem byly reformy, které Kapleau zavedl po návratu do USA v roce 1965, především použití anglického překladu Sútry srdce v zendó. ${ }^{64}$

Ke konci Jamadova života se objevuje problém ohledně oprávnění jeho žáků vyučovat zen. ${ }^{65}$ Redukce učení buddhismu, které obsahuje sofistikovanou literaturu, filosofii, rituály a liturgii, do jedné momentální zkušenosti osvícení, kterou může získat každý v relativně velmi krátké době (někdy jen měsíce), má za důsledek extrémní důležitost toho, kdo má, či nemá kenšó a kdo může kenšó verifikovat (autorizovat). ${ }^{66}$

Smrt Jamady v září 1989 tento problém vyostřila. Třetí opat Džiun Kubota se snažil formalizovat hierarchii vedení Sanbó Kjódan, ale

\footnotetext{
Srov. Koun Yamada. The Gateless Gate. The Classic Book of Zen Koans, s. xviii.

${ }^{64}$ Srov. Robert Sharf. Sanbōkyōdan: Zen and the Way of the New Religions, s. 446-447.

65 Když se David Scates otázal po pověrovacích listinách Kapleaua, Jamada v roce 1986 odpověděl, že Kapleau nikdy nedokončil kóanový výcvik a neobdržel tzv. inka - předání. Kapleau ale obdržel kenšó certifikát. Z toho plynou problémy, např. zdali povolení učit znamená povolení potvrdit kenšó nebo co vlastně znamená povolení učit. Srov. tamtéž, s. 447.

66 Srov. tamtéž, s. 454.
} 
po dlouhém období nejasností odchází Robert Aitken, potvrzený Jamadou jako nezávislý mistr. ${ }^{67}$

Osamostatnění se týkalo i křestanských žáků. Willigis Jäger formálně opustil Sanbó Kjódan v roce 2009, založil vlastní nezávislou školu a zavázal se, že nebude nadále oficiálně vystupovat jako zenový mistr Sanbó Kjódan. ${ }^{68}$ Osamostatnil se i jezuita Ama Samy, který založil vlastní zenovou linii Bódhi Sangha, v níž také autorizoval další učitele. ${ }^{69}$

Základem Sanbó Kjódan zůstává soustředění na jeden cíl: kenšó. Vše ostatní je zbytné a nepodstatné (včetně studia základních buddhistických doktrín). Rozlišuje se tak cíl či esence zenu, tj. kenšó, a prostředky vedoucí k tomuto cíli. Tato esence je pak považována za transkulturní a transhistorickou náboženskou zkušenost. ${ }^{70}$ Kenšó je tak odtrženo od buddhistického kontextu. Kenšó není nabízeno jako přerušení či ukončení sansáry (nekonečného koloběhu znovuzrození) ${ }^{71}$, ani nebývá meditační praxe diskutována z pohledu tradičního konceptu bódhisattvovy cesty, tedy úmyslu být opakovaně znovuzrozen, aby mohl zachránit všechny bytosti.

Dá se tedy konstatovat, že důraz na kenšó, který byl jednou z hlavních příčin vzniku Sanbó Kjódan a který se rozvinul až do pojetí kenšó jako transreligiózní, transhistorické a transkulturní zkušenosti, zůstává jeho základem dodnes. ${ }^{72}$

\section{Křestananští učitelé zenu}

\subsection{Hugo Makibi Enomiya-Lassalle SJ}

Hugo Lassalle (1898-1990) se narodil v německém Externbrocku. V roce 1919 vstoupil do jezuitského řádu a dva roky po vysvěcení na kněze (1927) odjel do Japonska, kde strávil prakticky celý život. Od roku 1940 byl vikářem v Hirošimě, kde byl 6. srpna 1945 vážně zraněn při výbuchu atomové bomby. V roce 1948 získal japonské

\footnotetext{
To znamená, že byl oprávněn založit vlastní linii a autorizovat mistry.

68 Srov. Ryoun Yamada. Report on the Kenshukai in Tagaytay (1-6 November 2009). Kyosho 2010, č. 340, s. 5-6.

${ }_{69}$ Viz http://www.bodhisangha.net/index.php/en/bodhisangha-engl [2016-9-15].

70 Srov. Robert Sharf. Sanbōkyōdan: Zen and the Way of the New Religions, s. 435.

71 Dosl. „koloběh životů“, sled znovuzrození, jimiž každá bytost prochází, dokud nedosáhne vysvobození. Srov. Lexikon východni moudrosti, s. 382.

72 Srov. Sanbô-Zen oficiální stránka, články People do not die a Is Zen a 'religion'? http://www.sanbo-zen.org/top_e.html [2014-11-18].
} 
občanství a přijal japonské jméno Makibi Enomiya (znamená „chrám lásky“773). V roce 1968 pak obdržel titul čestný občan Hirošimy. ${ }^{74}$

Otec Enomiya-Lassalle se velmi zajímal o kulturu a náboženství hostitelské země a přál si skrze zen hlouběji pochopit japonskou duši. ${ }^{75}$ Od roku 1943 studoval zen a účastnil se seššinů vedených řadou učitelů, mimo jiné i Haradou a Jasutanim. ${ }^{76}$ Klíčovým učitelem však pro něho byl Kóun Jamada, který jej v roce 1978 autorizoval jako zenového učitele. Enomiya-Lassalle publikoval řadu knih, článků a přednášek na téma zen a křestanství. ${ }^{77}$

Enomiya-Lassalle nejen velmi usilovně praktikoval zen po mnoho let, ale snažil se prakticky i teoreticky pochopit a popsat vztah zenu a křestanství. Jeho reflexe vycházela z osobní zkušenosti s tím, jak mu zenová meditace pomohla na jeho duchovní cestě křestana. Zároveň si ale uvědomoval rozdíly mezi zenovým buddhismem a křestanstvím a snažil se promyslet, co je užitečné: „Není naším záměrem zpronevěřit se naší víře, ale jsou zde určitě věci, které se můžeme učit od Východu. Bylo by chybou si myslet, že se nemůžeme učit od zenu. Tato metoda existuje ve světě po staletí; je konsolidovaná a je za ní mnoho zkušeností.“78

Enomiya-Lassalle převzal především praxi meditace vsedě (zazen), včetně celkového uspořádání meditačních ústraní. ${ }^{79}$ Otázkou tedy bylo, jak používat zazen. Enomiya-Lassalle výslovně uvádí, že pro křestany je zenová metoda př́pustná pouze jako psychofyzická metoda, musí tedy být oddělena od buddhistického obsahu. Zen nezná křestanský pojem milost a její účinky, ${ }^{80}$ ale využívá lidskou přirozenost. „Zen je

73 William Johnston. Arise, My Love... Maryknoll, NY: Orbis Books 2000, s. 59.

74 Srov. Ursula Baatz. Hugo M. Enomiya-Lassalle, Ein Leben zwischen den Welten, Biographie. Zürich, Düsseldorf: Benziger 1998.

75 Srov. Josef Sudbrack. Er öffnete ein Tor. Zum Tod von P. Hugo M. Enomiya-Lassalle SJ (1898-1990). Materialdienst der EZW 1990, Evangelische Zentralstelle für Weltanschauungsfragen, roč. 53, s. 313.

76 První seššin absolvoval u róšiho Shimady, dále pak byl v kontaktu s těmito učiteli: Watanabe Genshu, Sógaku Harada, Sessui, Nagasawa, Jasutani. Srov. Ursula Baatz. Hugo M. Enomiya-Lassalle, Ein Leben zwischen den Welten, Biographie, s. 359.

77 Srov. bibliografie v Ursula Baatz. Hugo M. Enomiya-Lassalle, Ein Leben zwischen den Welten, Biographie, s. 478-487.

78 H. M. Enomiya-Lassalle. Zen - Way to Enlightenment. New York: Taplinger Publishing Company 1968, s. 97.

79 Asi nejúplnější popis v H. M. Enomiya-Lassalle. The Practice of Zen Meditation. London: Thorsons 1995.

80 Enomiya-Lassalle uvádí, že „přijatá milost“ není v zenu zmiňována. - H. M. Enomiya-Lassalle. The Practice of Zen Meditation, s. 76. Mnozí učitelé zenu ale zdůrazňují, že satori není něco, co můžeme získat. Např. Učijama: „Sedět s představou, že 
založen na využití výhradně přirozených sil.“81 Upozorňuje, že katolická církev nikdy neodmítla využití přirozených sil.

Zazen dle něho nemůže zcela nahradit křestanskou meditaci. ${ }^{82}$ Každý, kdo si chce osvojit křestanské pravdy, musí praktikovat i diskurzivní meditaci (rozjímání), ${ }^{83}$ ale není třeba se bát použít metody jiného náboženství, když nám pomohou zvnitřnit pravdy křestanství.

Pozitivní účinky zenu shrnul do dvou kategorií: ${ }^{84}$ „a) síly, které získáme praktikováním zenu ${ }^{85}$; b) vhled neboli intuitivní síla poznání.“86 Zazen je výborný prostředek pro osvobození se z denních myšlenek, napomáhá usebrání a může pomoci překonat některé potíže spojené s rozjímáním (např. vyprahlost, distrakce). Zazen je velmi vhodný pro jednoduchou kontemplativní modlitbu a může být užitečný i pro orální modlitby. To byla jeho vlastní zkušenost a byl přesvědčen, že každý si to může ověřit. ${ }^{87}$

Při použití zazenu tak dle něho není v sázce dogma, jde pouze o rozvinutí přirozených sil duše, která touží po osobním setkání s Bohem. A i když takováto zkušenost setkání s Bohem může nastat náhle a kdykoliv, je to vzácné a nelze na to spoléhat, ale musíme se sami maximálně snažit. Enomiya-Lassalle se obrací na lidi, kteří usilují o křestanskou dokonalost a přejí si využít zazen pro tento cíl. „Nicméně, meditace sama nedostačuje k tomu, stát se dokonalým. Vyjasněme si jednou a provždy: když někdo neustále neusiluje žít svobodný život bez hříchu a překonat své základní instinkty, žádná meditační metoda ho neposune na jeho duchovní cestě.“88 Buduje dům na písku (Mt $7,27)$, nebot „být křestany znamená žít své životy podle učení a příkladu Krista". 89

získáte osvícení, je totiž úplně směšné.“ - Kóšó Učijama. Uvolnit sevření mysli. Cesta $k$ zenu. Praha: DharmaGaia 2000, s. 49.

H. M. Ennomiya-Lassalle. Zen - Way to Enlightenment, s. 83.

Srov. tamtéž, s. 84 .

Srov. tamtéž, s. 87.

84 Na jiném místě uvádí ještě třetí účinek „osvícení neboli zření podstaty“, in: H. M. Enomiya-Lassalle. Zenová meditace, s. 57.

85 Myšlena především schopnost koncentrace, eliminace rozptýlení a duševní rovnováha.

86 H. M. Enomiya-Lassalle. Living in the New Consciousness. Boston \& Shaftesbury: Shambhala 1988, s. 116.

87 Srov. H. M. Enomiya-Lassalle. Zen - Way to Enlightenment, s. 86.

88 Tamtéž, s. 84-85.

89 Tamtéž, s. 87. 
Vedle využití zazenu byla pro Enomiyu-Lassalla klíčová otázka: Co je to kenšó? Silně toužil dosáhnout kenšó a vyzkoumat jeho podstatu. ${ }^{90}$ A už v roce 1959 ho róši Harada velmi povzbuzoval a během jednoho rozhovoru mu řekl, že když dosáhne kenšó, může to mít pro Japonsko velký význam. ${ }^{91} \mathrm{~V}$ roce 1974 na konci seššinu róši Jamada veřejně potvrdil, že Enomiya-Lassalle dosáhl kenšó, což bylo pro Enomiyu-Lassalla obrovské překvapení. Enomiya-Lassalle si nevzpomínal na žádný průlomový zážitek: „Toto uznání kenšó, o kterém nikdo nevěděl, kde, jak a kdy se událo, přišlo pro mne absolutně nečekaně. Nevěřil jsem vlastním uším a přišlo mi to, jako bych snil.“92 Jamada mu během dokusanu ${ }^{93}$ řekl, že si Enomiya-Lassalle pod vlivem filosofie vytvořil mylnou představu o kenšó, a proto si myslel, že ho nedosáhl. Jamada mu vysvětlil, že jeho kenšó může být křestanské kenšó, tedy něco jako zkušenost Boha („etwa eine Gotteserfahrung ${ }^{694}$ ), ale to je také kenšó. Dne 31. července 1974 slavil se souhlasem róšiho společně se všemi katolíky, kteří se zúčastnili seššinu, mši svatou. Na konci seššinu pak Jamada oficiálně vyhlásil, že Enomiya-Lassalle dosáhl kenšó, a „pokáral (...) japonské zenové mistry včetně sebe, že př́liš lpí na formě, co se týká kenšó “. 95

Tento seššin a zenovým mistrem potvrzené kenšó Enomiyi-Lassalla má i historickou dimenzi. Enomiya-Lassalle si do svého deníku poznamenal: „Róši mi řekl na závěr posledního dokusanu, že by rád dal celý zen katolicismu. To je jeho úkol. ${ }^{96}$ Ale jak tam má být integrován, musíme nalézt sami. ${ }^{97}$ Podobně také hovořil k ostatním.“98 Tímto spojením zenu s křestanstvím nabývá zcela nové podoby tradiční zenové

90 Srov. Ursula Baatz. Hugo M. Enomiya-Lassalle, Ein Leben zwischen den Welten, s. 266.

91 Srov. tamtéž, s. 276.

92 Tamtéž, s. 359.

93 Dokusan - rozhovor s mistrem o samotě. Žák má možnost přednést mistrovi všechny své problémy, které se mohou vyskytnout při cvičení, a ukázat svůj pokrok při řešení kóanu. Srov. Lexikon východni moudrosti, s. 116-117.

94 Ursula Baatz. Hugo M. Enomiya-Lassalle, Ein Leben zwischen den Welten, s. 358.

95 Tamtéž, s. 358-359.

96 V jedné promluvě Jamada říká: „Ačkoliv je samozřejmě klíčové, aby se zen stával hlubším, současně cítím, že musím pomoci i křestanství. A to i přesto, že jsme ještě nedošli k tomu, abychom mohli jednoduše začlenit zen do křestanství. Postupně jsme došli k tomu, že můžeme praktikovat bez strádání jako v minulosti, ale stále je dlouhá cesta před námi.“ In: Shôyôroku (Book of Equanimity) - case 81, s. 3; (http://www .sanbo-zen.org/top_e.html - komentáře Jamady dostupné pouze pro členy).

98 Tamtéž, s. 361. 
předávání podstaty zenu. Představitel křestanské tradice může oficiálně předávat učení zenového buddhismu.

Osvícení dle Enomiyi-Lassalla není poznání něčeho nového, nevíme pak více, než jsme věděli předtím, ale víme to, co jsme věděli předtím, novým způsobem. Je to zkušenostní vědění, ne teoretické. Co je tedy zakoušeno při osvícení? Zkušenost něčeho, co lze nazvat pravé já (hlubší já) jako protiklad empirického já (běžně zakoušeného já). A to nelze nijak popsat slovy. Druhou odpovědí je, že osvícení je zkušenost nerozdělené a absolutní reality. Ta může být zakoušena jako osobní nebo neosobní. ${ }^{99}$

Pravá mystická zkušenost, zdůrazňuje Enomiya-Lassalle, odolá pokusům o konceptuální vyjádření. Snaha o použití slov snadno vede k nedorozumění. Zkušenost osvícení může být interpretována křestansky nebo buddhisticky, ale kdo osvícení zakusil, má zkušenost svobody od strachu a pochyb, zkušenost hlubokého míru a radosti. At' interpretováno v buddhistickém, nebo křestanském smyslu, osvícení je dle Enomiyi-Lassalla ${ }^{100}$ bezpochyby drahocenná zkušenost, která, když je vskutku správně pochopena, je možná nejcennější zkušeností, jaké je člověk schopen. ${ }^{101}$

Obrazně řečeno, Enomiya-Lassalle vyjmul některé spirituální zenové praktiky a vložil je do křestanského základu. Přitom nalezl mnoho shod s mystickou tradicí v křestanství, což jej utvrdilo v přesvědčení, že tento proces absorpce některých zen buddhistických praktik je nejen možný a prospěšný, ale že to v základu není pro křestanství nic nového. Podstatné je, že zenová praxe zůstává vnořena do celku křestanství jako užitečná, ale volitelná součást. Enomiya-Lassalle explicitně trval na svátostném životě i rozjímavé modlitbě. Můžeme tedy říci, že při tomto př́stupu ,je křestanská modlitba vždy podmíněna strukturou křestanské víry, v níž září pravda o Bohu a o stvoření“. ${ }^{102}$ To je oficiální, i když mnohem později definované kritérium, podle kterého lze posoudit, „zda a jakým způsobem mohou naši modlitbu obohatit

${ }^{99}$ Srov. H. M. Enomiya-Lassalle. Living in the New Consciousness, s. 121.

100 Stojí za povšimnutí, že popis kenšó se v některých vlastnostech významně liší oproti Suzukimu: zkušenost kenšó není náhlá (nemá charakter průlomu), nemá nutně neosobní charakter (i když ho může mít) a rozum zůstává částečně aktivní (fungující intuitivně na jiné úrovni).

101 Srov. H. M. Enomiya-Lassalle. Living in the New Consciousness, s. 122.

102 Josef Ratzinger. List biskupům katolické církve o některých aspektech křestanské meditace z 15. 10. 1989. In: Křestanství a ostatní náboženství - Dokument Mezinárodní teologické komise z roku 1996. Praha: Krystal OP 1996, s. 67. 
metody meditace, jež se zrodily v jiných kulturních a náboženských kontextech“. ${ }^{103}$

Životní i duchovní cesta Enomiyi-Lassalla nebyla snadná. Potýkal se s nepochopením prakticky ode všech, jeho knihy, především na počátku, vycházely s velkými obtížemi a vyvolávaly polemiky. Některé jeho názory byly předmětem kritiky, nikdo ale nezpochybnil jeho lidské hodnoty a oddanost křestanství. Jamada jednou řekl: „V zenu je otec Lassalle můj student, ale pokud jde o charakter, je můj učitel.“104 Ve svém deníku si Enomiya-Lassalle poznamenal, že nehledá pozornost, ale spíše opovržení. To bylo pro něho následování Krista. Jeho motem bylo „Ama nesciri et pro nihilo reputari“. ${ }^{105}$

Jezuita Hugo Makibi Enomiya-Lassalle je plným právem považován za průkopníka v porozumění mezi zen buddhismem a křestanstvím. Zemřel 7. července 1990 po několika operacích v Münsteru, poté co se vrátil do Německa z důvodu nemoci.

\subsection{Willigis Jäger OSB}

Benediktinský mnich a kněz Willigis Jäger se narodil v roce 1925 v Německu. Dle vlastního svědectví zakusil první mystickou zkušenost jako pěti- nebo šestiletý, když byl s matkou v kostele. Tato zkušenost byla pro něho rozhodující, protože od této chvíle mu bylo naprosto jasné, že chce být knězem. ${ }^{106} \mathrm{~V}$ roce 1952 byl na kněze vysvěcen. ${ }^{107}$

Od roku 1969 praktikuje zen v Japonsku, nejprve v zenovém centru založeném Enomiyou-Lassallem a od roku 1972 jako žák róšiho Jamady. Od roku 1985 vyučuje zen v Evropě a v roce 1996 dostal od róšiho Kuboty (nástupce Kóuna Jamady) oprávnění k vyučování. Jako mistr zenu tak mohl cvičit a autorizovat další mistry ve škole Sanbó Kjódan ${ }^{108}$ až do ledna 2009, kdy se formálně odloučil od Sanbó Kjódan a vytvořil

\footnotetext{
103 Tamtéž, s. 67.

104 Koun Yamada. Christian Practitioners of Zen. Kyosho 2012, č. 356, s. 32.

105 „(Chceš-li co prospěšného věděti a se naučiti) bud' rád světu neznám a za nic považován.“ - Tomáš Kempenský. Čtvero knih o následováni Krista. Praha: Arcibiskupská tiskárna (Rohlíček a Sievers) 1900, s. 21.

${ }^{106}$ Srov. Christoph Quarch (ed.). Mysticism for Modern Times. Conversation with Willigis Jäger. Liguori, MO: Liguori / Triumph 2006, s. 89.

107 Srov. http://www.willigisjaeger-foundation.com/willigis-jaeger/biography.html [2017-2-22].

108 Srov. Joachim Süss. Der Benediktushof - Zentrum für spirituele Wege. In: Peter Schreiner - Ursula Sieg - Volker Elsenbast (eds.). Handbuch Interrelligiöses Lernen. Gütersloh: Gütersloher Verlagshaus 2005, s. 633-639.
} 
vlastní školu. ${ }^{109}$ Ve stejném roce byl potvrzen čínským buddhistickým velmistrem Jing Hui jako 45. nástupce čínské čchanové tradice Lin-ti-cung (v japonském prostředí jde o zenovou školu Rinzai). ${ }^{110}$

$\mathrm{V}$ roce $2002 \mathrm{mu}$ bylo nařízeno tehdejším prefektem Kongregace pro nauku víry kardinálem Ratzingerem přerušit veškeré veřejné aktivity včetně publikování. Předmětem výtek bylo snižování významu osobního Boha a nadřazení mystické zkušenosti pravdám víry. ${ }^{111}$ Jäger krátce tento zákaz dodržoval, ale velmi brzy začal opět vyučovat a v roce 2003 i publikovat. ${ }^{112}$

V současnosti Willigis Jäger žije $\mathbf{v}$ protrahované exklaustraci ${ }^{113}$ a pracuje $\mathbf{v}$ Benediktushof (centrum pro duchovní cestu) v Holzkirchenu, jehož je zakladatelem. Je také zakladatelem mezinárodní nadace „West-Östliche Weisheit Willigis Jäger Stiftung“, ${ }^{114}$ jejímž hlavním cílem je vedení lidí k transkonfesijní a transpersonální zkušenosti skutečnosti, ${ }^{115}$ a spoluzakladatelem a iniciátorem četných center v Německu a Evropě. Jen v Německu existuje více než 100 místních meditačních skupin a seznam Jägerem autorizovaných učitelů zenu a kontemplace čítá několik desítek jmen. ${ }^{116}$

Jäger se prezentuje jako zenový a kontemplační mistr, zakladatel zenové linie Prázdný mrak ${ }^{117}$ a představitel moderní mystiky, která je založena jak na křestanské mystice, tak i na zenové tradici, ale zároveň překračuje tyto tradiční koncepty a jeho vize se odvolává i na to, že integruje poslední vědecké poznatky. ${ }^{118}$

109 Srov. http://www.sanbo-zen.org/0111announcement.pdf [2016-7-15].

110 Srov. http://www.willigisjaeger-foundation.com/zen/kyo-un-roshi.html [2017-2-22].

111 Srov. http://www.thefreelibrary.com/Two+more+scholars+censured+by +Rome.+(World).-a084092217 [2016-8-5].

112 Willigis Jäger. Search for the Meaning of Life. Essays and Reflections on the Mystical Experience. Liguori, MO: Liguori/Triumph, revidované vydání 2003 (E-book).

${ }^{113} \mathrm{Z}$ lat. exclaustratio, doslova mimo (ex) klášter (claustrum). Kanonický akt (prominutí života v klášteře), kterým se povoluje řeholníkovi s věčnými sliby žít z vážných důvodů po určitý čas, nepřekračující dobu tří let, mimo společenství. O exklaustraci může požádat sám řeholník nebo mu může být uložena nadřízenými (CIC, kán. 686).

114 Srov. http://willigisjaeger-foundation.com/willigis-jaeger/97-portrait.html [2016-8-5].

115 Srov. http://www.benediktushof-holzkirchen.de/stiftung/117-stiftungszweck.html [2017-2-22].

116 Srov. http://willigisjaeger-foundation.com/zen/lehrer/list-of-teachers.html a http:// willigisjaeger-foundation.com/kontemplation/die-lehrenden/list-of-teachers.html [2016-9-15].

117 Srov. http://www.willigisjaeger-foundation.com/zen/kyo-un-roshi.html [2017-2-22].

118 Srov. Willigis Jäger. Search for the Meaning of Life. Essays and Reflections on the Mystical Experience. Liguori, Missouri: Liguori/Triumph, revidované vydání 2003 (E-book), kapitola 2. Science and Mysticsm nebo. http://www.willigisjaeger 
Ve svých knihách ${ }^{119}$ ztělesňuje spiritualitu, ${ }^{120}$ která určitým způsobem dovádí do důsledku myšlenku školy Sanbó Kjódan, že esence zenu je výhradně a výlučně kenšó, transkulturní a transhistorická náboženská zkušenost, a vše ostatní jsou jen prostředky vedoucí k tomuto cíli. ${ }^{121}$

Hovoří o tzv. čtyřech úrovních vědomí1 ${ }^{122}$, kde nejvyšší stupeň, kosmické vědomí, je charakterizován termíny prázdnota, božství, základ, šúnjatá ${ }^{123}$, Tathágata ${ }^{124}$. „Zde se zakouší zkušenost čirého bytí, zdroje, z něhož všechno prýští. Je to úroveň, která nutně předchází všemu, co může vejít v existenci. Zde mystik objevuje, že bytí není nic jiného než to, co z tohoto vystupuje (emerguje). (...) Přirozenost a nadpřirozenost nejsou dva. V zenu je to úroveň, na které se osvícená osoba vrací na tržiště. ${ }^{125}$ Všechny věci jsou jedno, a přece zůstávají oddělené jedna od druhé.“126 Všechna náboženství a posvátné texty jsou vyjádřením takové hluboké mystické zkušenosti a úkolem náboženství je jednotlivce k takové zkušenosti probudit.

Mystická zkušenost je dle Jägera dokonalá a naplňující, bezčasá, nesdělitelná a je probuzením Boha. Mystické vědomí je dle něho

-foundation.com/willigis-jaeger/97-portrait.html [2017-2-22] nebo Willigis Jäger. Contemplation - A Christian Path. Liguori, Missouri: Liguori/Triumph, revidované vydání 1994 (E-book), kapitola Contemporary Considerations in Contemplation.

119 Seznam publikací o zenu http://www.willigisjaeger-foundation.com/zen/publikationen .html; publikace o kontemplaci http://www.willigisjaeger-foundation.com/kontem plation/publikationen.html.

120 Willigis Jäger. Jenseits von Gott. Holzkirchen: Wege der Mystik 2014; týž. Search for the Meaning of Life. Essays and Reflections on the Mystical Experience. Liguori, MO: Liguori / Triumph, revidované vydání 2003 (E-book); týž. Contemplation - A Christian Path. Liguori, MO: Liguori / Triumph, revidované vydání 1994 (E-book); Christoph Quarch (ed.). Mysticism for Modern Times. Conversation with Willigis Jäger. Liguori. MO: Liguori / Triumph 2006.

${ }^{121}$ Srov. Robert Sharf. Sanbōkyōdan: Zen and the Way of the New Religions, s. 435.

${ }^{122}$ Odkazuje se na Kennetha Earl Wilbera (* 31. leden 1949), amerického spisovatele o transpersonální psychologii, a jeho „Integrální teorii“ čtyř úrovní vědomí, která se snaží zahrnout veškeré lidské vědění a zkušenost.

123 Šúnjatá je ústřední pojem buddhismu a znamená doslova prázdno či prázdnota. V mahájáně jsou všechny věci chápány jako bezpodstatné, tj. prosté vlastní přirozenosti. Srov. Lexikon východni moudrosti, s. 440.

124 Tathágata, doslova „ten, jenž takto dospěl, Dokonalý“, je označením pro toho, který dospěl k nejvyššímu osvícení. Srov. Lexikon východni moudrosti, s. 459.

125 „Osvícená osoba se vrací na tržiště“ je odkazem na 10 obrazů krocení býka, které popisují stupně duchovní cesty. Desátý, tedy poslední, obraz ukazuje osvíceného, jak vstupuje na tržiště a chová se jako zcela obyčejný člověk. Ale zároveň díky jeho osvícení je vše, co dělá, zcela mimořádné.

${ }^{126}$ Willigis Jäger. Search for the Meaning of Life. Essays and Reflections on the Mystical Experience. E-book (3. kapitola Transpersonal Experience). 
oblast zkušenosti, kde jsou věci tak, jak jsou, a jako takové jsou dokonalé. $V$ tomto vědomí nelišnosti a nerozlišenosti nejsme ani štastní, ani neštastní, ani spokojení, ani nespokojení. Není zde ani objekt, ani subjekt, jen bytí. Ale zároveň jsou naplněny všechny naše touhy. Zde jsme nakloněni říci „Já jsem Bůh“. ${ }^{127}$ Tato zkušenost je mimo prostor a čas, protože na rozdíl od měnících se představ, symbolů a jazyka toto božské zůstává nedotčeno změnou, ačkoliv je esencí všeho, co se mění. Esenciální jádro každého náboženství je zkušenost této poslední (nejzákladnější) skutečnosti, která transcenduje všechna ohraničení a limity prostoru a času. Tato ohraničení a limity jsou vytvořeny výhradně skutečností, že lidé chtějí určit (definovat) koncepty toho, co je nevýslovné. Na úrovni zkušenosti jsou tak všechna náboženství jedno. ${ }^{128}$

Jäger shrnuje svou mystickou zkušenost v rozsáhlé básni nazvané Mé vyznání, kde mimo jiné píše:

JEDNO je moje pravá přirozenost

a přirozenost všeho jsoucího.

Je bezčasé a neměnné, rozvíjí se v čase.

Zjevuje (ukazuje) se jako tato forma, kterou jsem já.

Nevzniklo mým narozením, nezaniká smrtí.

Není ani dobré, ani zlé

a s ničím není srovnatelné. ${ }^{129}$

...

Nemá nic společného s vírou, lze ho jen zakusit.

Je bez hranic, absolutní nyní. $\cdots$

Existuje jen bezčasové ted'.

Kdo této zkušenosti dosáhne, zakusí se jako jednota, celistvost a láska.

Tato láska vede ke společenství se všemi a s každým. ${ }^{130}$

127 Tamtéž.

128 Tamtéž.

${ }^{129}$ V německém originále je velkými písmeny vyznačeno i ES (TO). Je tím myšleno TO JEDNO. Např. ES ist zeitloss ... ES enfaltet ... ES offenbart atd.

${ }^{130}$ Willigis Jäger. Jenseits von Gott. Holzkirchen: Wege der Mystik, 2014, s. 85-90. 
Jäger věří, že evoluce světa dosáhla významného milníku a vstoupila do fáze, kdy lidské vědomí bude transformováno a kdy mystik (ve smyslu transkonfesijní a transpersonální úrovně) je „příští stupeň našeho lidského bytí (Menschseins)““. ${ }^{131}$ „Zen vede na transpersonální rovinu. Tam není žádný buddhista ani žádný křestan. Mluvit např́iklad o křestanském zenu je nesmysl. Zen není ani buddhistický, ani křestanský. Ve zkušenosti překračuji své náboženské vyznání (konfesi). (...) Konfese má být cesta k transkonfesionální úrovni, která je posledním cílem. Tato úroveň je zároveň zásadní počátek (výchozí bod) pro všechny konfese."132

Vše je tak zcela směřováno k oné zkušenosti jednoty a zároveň taková zkušenost je východiskem našeho pravého lidství, etického jednání a budoucnosti lidstva. $V$ jeho formulacích je implicitně obsaženo, že Willigis Jäger plně dosáhl tohoto cíle a je přesvědčen, že na základě výše popsané zkušenosti je schopen rozpoznat, jak daleko na této cestě ostatní postoupili: ${ }^{133}$ „Když někdo přijde a svou zkušenost mi sdělí, lze říci, kde stojí a zdali se ke skutečné hluboké zkušenosti bytí prolomil.“134 A tak, když viděl Enomiyu-Lassalla během seššinu každý den v rohu místnosti, jak zcela sám slouží mši svatou, bylo mu jasné, že Enomiya-Lassalle nedokázal překročit svou víru. ${ }^{135}$ Sloužení mše svaté, stejně jako ostatní liturgie (a nejen ona) jsou pouze prostředkem k osvícení, a tak jsou po osvícení zbytné. Proti tomu se ovšem ohradil jiný křestanský učitel zenu, Johannes Kopp, který ve svém př́íspěvku mimo jiné píše, že žádný křestanský žák nemohl u róšiho Jamady pozorovat očekávání, že by měl překročit svou víru ve smyslu zenu bez náboženství (religionsfreien Zen). ${ }^{136}$

S určitou mírou zjednodušení tedy můžeme shrnout, že škola Willigise Jägera se vyznačuje výrazným důrazem na kontemplativní

${ }^{131}$ Hartmut Meesmann (ed.). Mystik - der wahre Weg zu Gott? Die Kontroverse um den Benediktinerpater und Zen-Lehrer Willigis Jäger. Oberursel: Publik-Forum 2010, s. 141.

132 Tamtéž, s. 137.

${ }^{133}$ Zde se otevírá otázka, nakolik tato schopnost patří k tradiční úloze zenového mistra a do jaké míry je tato role totožná s úlohou duchovního rádce v křestanství. Je to otázka podstatná, ale i složitější, než se na první pohled zdá. Odpověd' je tak mimo dosah této práce.

${ }^{134}$ Willigis Jäger, in: Hartmut Meesmann (ed.). Mystik - der wahre Weg zu Gott? Die Kontroverse um den Benediktinerpater und Zen-Lehrer Willigis Jäger, s. 143.

155 Srov. tamtéž, s. 21.

${ }^{136}$ Srov. Johannes Kopp, in: Hartmut Meesmann (ed.). Mystik-der wahre Weg zu Gott? Die Kontroverse um den Benediktinerpater und Zen-Lehrer Willigis Jäger, s. 51-54. 
zkušenost, která je absolutně nadkonfesijní a je cílem veškerého duchovního života a zároveň východiskem i důvodem každého náboženství. Úkolem a hlavní funkcí náboženství je vést k této zkušenosti. Je nepopiratelné, že Willigis Jäger oslovil nemalý počet duchovně hledajících lidí. Zároveň ale je kritizován především pro dvě věci: pro absolutizaci ahistorické a transkonfesionální zkušenosti a pro některé názory spojené s etikou.

Absolutizace čisté zkušenosti odvolávající se na philosophia perennis je kritizována především z pohledu tzv. kontextualismu, který zdůrazňuje důležitost kontextu pro porozumění jakékoliv mystické zkušenosti. Mezi hlavní výtky ${ }^{137}$ patří naivní pohled na lidskou zkušenost, selektivní výběr primárních mystických textů a nezpochybnitelný předpoklad, že existuje jeden dokonalý zdroj za hranicemi všech náboženství. Každá kontemplativní praxe, namítají odpůrci čisté zkušenosti, využívá specifický pohled na svět a začleňuje praxi i praktikujícího do širšího systému. Takový systém obsahuje charakteristický pohled na sebe, na svět, náboženské a teologické záležitosti a závazky, další formy duchovní praxe atd. Toto začlenění brání izolování kontemplativní (či meditativní) praxe a jejímu redukování na pouhou techniku nebo zkušenost. ${ }^{138} \mathrm{~V}$ následující kapitole uvidíme, že mezi kritiky absolutizace čisté zkušenosti patří i Ama Samy, další křestanský učitel zenu, autorizovaný róšim Jamadou.

Druhým velmi sporným bodem je otázka etiky, především jejího vztahu k zenovému osvícení. Opravdové mravní konání vychází dle Jägera právě z oné transkonfesijní zkušenosti jednoty, která je pramenem mravnosti, a zároveň právě a jedině zkušenost osvícení (kenšó) je příčinou, která uschopňuje ke skutečně mravnímu jednání. „Z hlediska mystiky není hřích v podstatě nic víc než nedostatek realizace. Ti, kteří vstupem do transpersonální sféry realizovali svou pravou esenci a zbavili se své fixace na ego, se budou chovat eticky."139 Ovšem problém nastává, jak rozlišit dobré a zlé, protože tento „pramen“ obsahuje jak to, co nazýváme dobré, tak to, co považujeme za zlo. Na toto

${ }^{137}$ Srov. Louis Komjathy (ed.). Contemplative Literature. A Comparative Sourcebook on Meditation and Contemplative Prayer. New York: State University of New York 2015, s. 14.

138 Srov. tamtéž, s. 22.

${ }^{139}$ Christoph Quarch (ed.). Mysticism for Modern Times. Conversation with W. Jäger, s. 117. 
téma vyvolala rozsáhlou diskuzi Ursula Baatz ${ }^{140}$, když v kritice Willigise Jägera napsala, že klást do jedné roviny např. holocaust a tsunami znamená ztrácet schopnost rozlišování, která vždy byla v křestanství, ale i v buddhismu kritériem duchovní zralosti.

Otázka, jak se konstituuje rozlišování ze zkušenosti, která je čistá a nerozlišená, není ale jediná. Další velmi spornou otázkou je, jak osvícení, prožitek zkušenosti sjednocení, zajistí mravní jednání. Vždyt' právě róši Jasutani a jeho učitel Harada byli oprávněně kritizováni za své militantní postoje. ${ }^{141}$ Pokud by Jasutani nebyl osvícený, pak by byla zpochybněna celá linie Sanbó Kjódan, a to dle vlastního kritéria. Pokud byl osvícený a osvícení je zdrojem a příčinou mravního jednání, jak mohl selhat? Jäger se pokouší toto dilema vysvětlit podmínkami, za kterých byli Jasutani a Harada v dětství vychováváni, a dodává: „A mimochodem, byli schopni sladit své postoje s učením zenu bez větších obtíží. Protože vše je jednoduše forma stejného kosmického života, tak smrt jednotlivce sotva způsobí rozdíl v univerzálním procesu božské evoluce. Evoluce pokračuje i přes vyvraždění milionů. To je její strukturální princip.“ ${ }^{142}$ Na zděšení editora nad touto odpovědí Jäger reaguje upřesněním: „Nechci ospravedlňovat chování róšiho Jasutaniho a róšiho Harady ani jejich myšlenkové modely, které vedly k takovému jednání. (...) Považuji za zcela chybné odvozovat sociální ideje ze strukturálního principu evoluce. To je sotva akceptovatelné, alespoň pro osobu s mystickým vědomím. Taková osoba - pokud je opravdový mystik - musí hájit pravý opak: mír. To je logický důsledek zkušenosti jednoty se všemi živými bytostmi.“"143 Takže Jasutani a Harada neměli pravou zkušenost, nebo „,během času vybledla a překryly ji návyky z dětstvi““. ${ }^{144}$ Jak zkušenost osvícení může vyblednout a co z toho plyne, zůstává nejasné. ${ }^{145}$

140 Srov. Ursula Baatz, in: Hartmut Meesmann (ed.). Mystik - der wahre Weg zu Gott? Die Kontroverse um den Benediktinerpater und Zen-Lehrer Willigis Jäger, s. 13-18.

${ }^{141}$ Srov. Brian Daizen Victoria. Zen at War.

${ }^{142}$ Christoph Quarch (ed.). Mysticism for Modern Times. Conversation with W. Jäger, s. 115.

143 Tamtéž, s. 116.

144 Tamtéž.

145 Podobnými otázkami v reakci na knihu Zen at War od Briana Daizena Victorii se zabývá Dale S. Wright, který ve svém článku tvrdí, že morální kultivace není považována za fundamentální či nezbytnou součást zenového osvícení. Dale S. Wright. Satori and the Moral Dimension of Enlightenment. Journal of Buddhist Ethics 2006, roč. 13, http://blogs.dickinson.edu/buddhistethics/files/2010/04/02_ZSE_Wright.pdf. 
Duchovní škola Willigise Jägera představuje specifický typ duchovní cesty, který vznikl interakcí křestanství a zen buddhismu. Jeho názory vyvolávají otázky i nesouhlas, ale na druhé straně jeho škola nejen přitahuje, ale je i pomocí pro mnoho lidí hledajících svou duchovní cestu, kteří nejsou (případně ani nechtějí být) členy některé křestanské církve. Právě jeho vedení a pomoc na duchovní cestě pro konfesijně nezařazené je mnohými považována za Jägerův nejdůležitější přínos, který je významnější než řešení otázky, zda duchovní cesta může či nemůže být transkonfesijní. ${ }^{46}$

\subsection{Ama Samy SJ}

Otec Ama Samy (narozen 1936 jako Arul Maria Arokiasamy) je dalším velmi známým křestanským žákem Jamady, který obdržel autorizaci učit zen a založil vlastní školu. ${ }^{147}$ Ama Samy pochází z Barmy z chudé indické rodiny. Jako chlapec se seznámil s barmským buddhismem, vychovával jej dědeček, sám velmi zbožný muslim. Když ten zemřel, byl chlapec nejprve odkázán sám na sebe, mohl ale navštěvovat školu vedenou jezuity v městě Madurai. Tam konvertoval a vstoupil do jezuitského řádu. ${ }^{148}$

Po studiích filosofie a teologie se stal knězem, ale stále toužil po prohloubení svého duchovního života. Zabýval se intenzivně křestanskou spiritualitou, ale zajímaly jej i východní techniky meditace. Začal navštěvovat hinduistické ašrámy a buddhistická meditační centra. Seznámil se s učením Ramana Maharšiho, které jej velmi zaujalo, a na nějaký čas se usadil jako poustevník při jednom poutním místě. ${ }^{149}$

Samy byl stále více přitahován zenem a nakonec mu Enomiya-Lassalle pomohl odjet do Japonska studovat zen pod vedením Kóuna Jamady, kde se stal v roce 1982 autorizovaným zenovým mistrem. Po smrti róšiho Jamady odešel ze Sanbó Kjódan a stal se nezávislým zenovým učitelem. ${ }^{150}$ Vrátil se do jižní Indie, kde založil centrum

\footnotetext{
146 Srov. Jan Šedivý, in: Hartmut Meesmann (ed.). Mystik-der wahre Weg zu Gott? Die Kontroverse um den Benediktinerpater und Zen-Lehrer Willigis Jäger, s. 91-98.

147 Bibliografie Ama Samyho viz http://www.bodhisangha.net/index.php/en /texts-teishos/books-english..

148 Srov. http://www.bodhisangha.net/index.php/en/home [2016-9-25].

149 Srov. tamtéž.

150 Srov. Ama Samy. Zen: Awakening to Your Original Face. Chennai: Cre-A, reprint 2010, s. 30 .
} 
meditace Bódhi Zendó ve státě Tamilnádu. ${ }^{151}$ Každý rok tráví několik měsíců v zahraničí, kde má mnoho žákủ. ${ }^{152}$

Přístup Ama Samyho k zenu a ke vztahu zenu ke křestanství se výrazně liší od názorů Willigise Jägera a v mnoha aspektech je zásadní kritikou podobných názorů. ${ }^{153}$ Je přesvědčen, že zen nelze cvičit bez kontextu, ale je třeba vstoupit do světa buddhismu. I když zen $\mathrm{v}$ určitém smyslu transcenduje buddhismus, je $\mathbf{v}$ něm zakořeněn. ${ }^{154}$ Po takovém studiu se lze s užitkem vrátit domů, tedy do křestanství, obohacen a s lepším porozuměním. Ama Samy také odmítá separaci duchovní zkušenosti od náboženského jazyka. „Bez náboženského jazyka není žádné náboženské nebo spirituální zkušenosti. Mnozí se chybně domnívají, že zen je mimo koncepty, jazyk a filosofiii. ${ }^{\text {“155 }}$ Ama Samy uznává, že existuje skutečnost a zkušenost bezpředmětové meditace, vědomého vědomí apod. Zdůrazňuje ale, že takové zkušenosti jsou nezbytně obsaženy, uznávány a ověřovány ve vědomé předmětné zkušenosti, nebot' interpretace a jazyk jsou součást lidského bytí, a tedy neexistuje žádné, od jazyka oproštěné (language-free) probuzení či realizace bez interpretace. ${ }^{56}$ Zenové probuzení obsahuje potvrzení vize zenového buddhismu. ${ }^{157}$ Dokonce i v zenovém buddhismu jsou některé interpretace probuzení mezi sebou v rozporu, nebot́ jsou vždy založeny na konkrétních textech a tradici.

V článku Zen and Christians ${ }^{158}$ kritizuje přístup mnoha křestanských učitelů zenu včetně Willigise Jägera a některých jeho žáků, ${ }^{159}$ jejichž přístup shledává hluboce mylný. Způsob, jak představují křestanský zen a důraz na zkušenost za slovy, považuje za individualistický

151 Srov. http://www.bodhisangha.net/index.php/en/home [2016-9-25].

${ }^{152}$ Ama Samy učil meditaci i v Praze. Srov. http://www.jesuit.cz/clanek.php?id=894 [2016-9-25].

153 Např́klad kritizuje pohled většiny učitelů zenu v: Michael Seitlinger - Jutta Höcht-Stöhr. Wie Zen mein Christsein verändert. Erfahrungen von Zen-Lehrern. Freiburg im Breisgau: Herder 2004.

154 Srov. Ama Samy. Zen: Fragrant Grasses, Falling Blossoms. India: Bodhi Zendo 2016, s. 128.

155 Ama Samy. Zen and Christians. The Way 2007, roč. 46, č. 2, s. 93.

156 Srov. Ama Samy. Zen: Awakening to Your Original Face, s. 82.

157 Samy vysvětluje, že když Jamada napsal o své zkušenosti kenšó, že „Já jsem zcela zmizel“, byl si plně vědom, co se mu přihodilo. Tedy jeho já nezmizelo, ale spíše bylo transformováno. Dále upozorňuje na to, že Jamadovo probuzení bylo zasazeno v kontextu dialogu s jeho učitelem Jasutanim a studiem Dogena a dalších. Srov. Ama Samy. Zen: Awakening to Your Original Face, s. 106.

${ }_{158}$ Ama Samy. Zen and Christians. The Way 2007, s. 89-102.

159 Jedná se o většinu autorů v knize: Michael Seitlinger - Jutta Höcht-Stöhr. Wie Zen mein Christsein verändert. 
a narcistní. ${ }^{160}$ Lidé mají často odstup od institucionálního náboženství, není ale přece možné se obejít bez společenství a etických předpisů. „Zen, aby byl pochopen a řádně praktikován, musí být umístěn v tradici a společenství.“161 Ama Samy sice připouští, že zenová meditace, zenová zkušenost a zenové probuzení není něco, co by bylo vyhrazeno pouze buddhistům, ale zen jako spiritualita by neměl být odtrháván od svého základu v buddhismu. ${ }^{162}$

Velmi kriticky hodnotí snahu založit etické jednání výlučně na osvícení. Dle Ama Samyho osvícení samo o sobě není schopno zajistit správné jednání ve světě založeném na rozlišování. „Náboženství jsou intimně svázána s morálkou (mravností). Mravnost, především odpovědnost k druhým, nelze obcházet. Mravnost nemůže být odůvodněna z ne-etického, údajně základnějšího, zorného úhlu. Pokus o to znamená neporozumění celé věci.“163 Jde o past transcendence, která se týká nejen mravnosti, ale i ne-myšlení v zenu. Vykreslení dokonalého mravního života jako ne-racionálního, přirozeného, spontánního, ne-lingvistického a nekalkulujícího je dle něho omylem. Tvrzení róšiho Jasutaniho, že „buddhismus jasně ukazuje, že rozlišující myšlení leží v kořenech falešných představ (klamu)“ a „myšlenka je nemoc lidské mysli“ ${ }^{164}$ je dle Samyho zcela mylné. Mystika například má noetickou kvalitu, porozumění a moudrost. Bez porozumění a rozumu skončí člověk jako slepý a nemorální. Moderní školy zenu se také dle Samyho příliš zaměřují na zkušenost, jako kdyby osvícení bylo pouze o zkušenosti. Dle Samyho „probuzení je pochopení, ne zvláštní zkušenost. Dojde k tomu ve zkušenosti, ale není to zkušenost" ${ }^{165}$

Předání učení, tak důležité v zenovém buddhismu, není tedy uznání nějaké zkušenosti, ale potvrzení realizace, tedy pochopení a jeho uskutečnění. Považovat ne-pojmovou či ne-konceptuální zkušenost za osvícení je chybné. Právě pro současné západní pojetí buddhismu je typické přehánění role zkušenosti, k čemuž významně přispěla i škola Sanbó Kjódan svým cíleným důrazem na zkušenost kenšó, na „osobní

\footnotetext{
${ }^{160}$ Srov. Ama Samy. Zen and Christians. The Way 2007, s. 93-94.

161 Ama Samy. Zen: Awakening to Your Original Face, s. 13.

162 Srov. tamtéž, s. 16.

163 Ama Samy. Zen: Fragrant Grasses, Falling Blossoms, s. 128.

${ }^{164}$ Tamtéž, s. 132.

165 Tamtéž.
} 
transformaci“, „vymýcení ega“, dosažení uskutečnění psychologického a duchovního „well-being“" nyní a zde. ${ }^{166}$

Pro osobní přístup Ama Samyho je důležitá dvojí náboženská příslušnost ${ }^{167}$ ve smyslu paralelního prožívání dvou náboženských tradic (například křestanství a buddhismu, nebo židovství a buddhismu). Ama Samy popisuje takovou možnost jako přechod a návrat domů. To znamená přechod křestana do buddhistické tradice a po nějaké době návrat ke křestanství. Tento přechod ale nelze zaměňovat pouze se studiem jiné tradice nebo využitím některých jejích prvkủ. Je třeba nejdříve v určitém slova smyslu zemřít svému vlastnímu náboženství a tradici a vstoupit do zenu a zenové tradice. ${ }^{168}$ Zde se jedná o hluboké a náročné (nejen časově) vnoření se do celé tradice a je zřejmé, že toto je i teoreticky možné jen pro velmi omezený okruh lidí. Ama Samy uznává, že tento proces má i svá rizika (například synkretismus, tj. smazávání hranic jedné či druhé tradice, nedostatek oddanosti jedné komunitě, či dokonce její zrazení), může ale dle něho být pro jednotlivce i komunitu požehnáním. Obě tradice tak mohou být obohaceny, což může vyústit ve větší vzájemnou toleranci, porozumění a respekt. ${ }^{169}$

Svou vlastní pozici popisuje jako blízkou dvojí náboženské příslušnosti, ale přece jen odlišnou. „Jsem křestan a zenový mistr. Když slavím mši svatou nebo křestanské obřady, jsem zcela křestan. Sdílím křestanské vnímání světa a vyjadřuji křestanský pohled. Když praktikuji zen, jsem zcela zenová osoba. Sdílím zen-buddhistické vnímání světa a učím a vyjadřuji zenový pohled, zenovou zkušenost a kázeň.“"170 Pohybuje se volně mezi zenem a křestanstvím bez vzájemného míchání (zen pro něho zůstává zenem a křestanství křestanstvím), ale jeho nejvlastnější pozice je v meziprostoru. „Stojím mezi oběma těmito tradicemi nebo náboženstvími v meziprostoru (,in-between`). Tento meziprostor je oblast nevědění a temnoty, lze říci, že je to oblak nevědění. Je to dimenze toho, co zen nazývá prázdnota. (...) Ten meziprostor je

\footnotetext{
${ }^{166}$ Srov. tamtéž, s. 133. Ama Samy v tomto souhlasí s Robertem Sharfem a cituje z něho. Srov. Robert Sharf. Sanbōkyōdan: Zen and the Way of the New Religions, s. 417-458.

167 Definování problému dvojí náboženské příslušnosti (dual belonging) a základní přehled in: Peter C. Phan. Multiple Religious Belonging: Opportunities and Challenges for Theology and Church. Theological Studies 2003, roč. 64, s. 495-519.

168 Srov. Ama Samy. Zen: Awakening to Your Original Face, s. 17.

169 Ama Samy. Zen: Fragrant Grasses, Falling Blossoms, s. 144.

170 Tamtéž, s. 145.
} 
oblast prázdnoty; nemůžete setrvat v prázdnotě; ale můžete ji pochopit a dát skutečnou podobu (,realize').“171

Interakce mezi křestanstvím a zenovým buddhismem se zde ukazuje ve třetím typu, který se podstatně liší od obou výše popsaných. Ponecháme-li stranou velice specifickou pozici Ama Samyho, tedy onen výše zmíněný meziprostor (in-between), a otázky a problémy spojené s dvojí, nebo dokonce vícečetnou náboženskou př́slušností172, můžeme konstatovat, že naprosto klíčové pro Ama Samyho je zakotvení zenu v kontextu buddhismu. „Tak zen bez zen buddhistických symbolů, rituálů, súter, tradice a praxe je redukován na nesmyslné blábolení. “173 Užitečnost vzájemné interakce zen buddhismu a křestanství není v žádném př́ípadě zpochybňována a ani užití některých metod zenu k prohloubení křestanské spirituality. Je ale nezbytné respektovat jinakost obou náboženství, která mohou souznít jako dvě různé struny na nástroji. Nesmíme ale zapomínat, že „buddhistický a křestanský popis absolutní reality není kontradiktorický ani komplementární, ale prostě nesrovnatelný“. 174

\section{Závèr}

Róši Jamada si přál „dát celý zen katolicismu“175 a domnívám se, že $v$ nějaké míře se mu to povedlo. Po jeho smrti byl nalezen seznam 22 nejaponských žáků, kteří pod jeho vedením dokončili kompletní zenový výcvik. ${ }^{176}$ Polovina z nich byly ženy a 12 byli křestané, z nichž 8 byli kněží nebo řádové sestry. Mezi nejznámější patří Hugo Makibi Enomiya-Lassalle SJ, Willigis Jäger OSB, Ama Samy SJ, Niklaus Brantschen SJ, Johannes Kopp SAC, sestra Ludwigis Fabian OSB, Elaine

171 Tamtéž.

172 Tato zajímavá problematika je zcela mimo dosah této práce. Základní přehled in: Peter C. Phan. Multiple Religious Belonging: Opportunities and Challenges for Theology and Church, s. 495-519; nebo in: Catherine Cornille. Many Mansions? Multiple Religious Belonging and Christian Identity. Eugene, OR: Wips and Stock 2002. Pro vztah křestanství a buddhismu např. in: Rose Drew. Buddhist and Christian? An exploration of dual belonging. London, New York: Routledge 2011.

173 Ama Samy. Zen Ancient and Modern: The Way to Heart Mind. Dindigul: Vaigarai Publishing House 2010, s. 208.

174 Tamtéž, s. 197.

175 Ursula Baatz. Hugo M. Enomiya-Lassalle, Ein Leben zwischen den Welten, s. 361.

176 Srov. Ruben L. F. Habito, in: Memoriam: Yamada Koun Roshi. Christian Studies 1990, roč. 10 , s. $232-233$. 
MacInnes OLM a bývalý jezuita Ruben Habito ${ }^{177}$. Interakce křestanství se zenovým buddhismem tak pokračuje v rozmanitých modifikacích, které inspirují i provokují, vzbuzují zájem i obavy a odmítání.

Přes všechny otázky a výhrady by nám Enomiya-Lassalle, Ama Samy i Willigis Jäger měli být připomínkou, že by nebylo správné odmítat hodnotu zenového buddhismu včetně jeho propracované metody, která se snaží připravit cestu ke zkušenosti transcendence sebe. „Aniž bychom tvrdili, že existuje úplná jednota všech náboženství na ,vrcholu', na transcendentní či mystické úrovni, (...) je jistě pravda, když řekneme, že i tam, kde jsou neslučitelné rozdíly v doktríně a ve vyjádřeném přesvědčení, tam přesto mohou být velké podobnosti a analogie ve sféře náboženské zkušenosti.“" ${ }^{178}$ Jsem přesvědčen, že vzájemná otevřenost róšiho Jamady a jeho křestanských žáků a vzájemný respekt k duchovní cestě toho druhého jsou př́klady hodnými následování. Stejně jako jejich intuice, že sebepoznání a kontemplativní zkušenost jednoty jsou důležité součásti duchovní cesty.

Na Př́kopè 28

11503 Praha 1

E-mail: booklover@o2active.cz

177 Jezuitský řád opustil v roce 1989 a v roce 1991 založil zenové centrum v Dallasu (Texas).

178 Thomas Merton. Mnišská zkušenost a dialog mezi Východem a Západem. Salve 1992, roč. 2., č. 3, s. 18. 